\title{
HUBUNGAN ANTARA PENGETAHUAN IBU TENTANG BABY BLUES, PROSES PERSALINAN, DAN PARITAS DENGAN BABY BLUES DI RSIA SRIKANDI IBI KABUPATEN JEMBER
}

\section{The Correlation Between Mother's Knowledge About Baby Blues, Childbirth Process and Parity with Baby Blues at RSIA Srikandi IBI in Jember District}

\author{
Putri Suci Wulansari ${ }^{1}$, Erdi Istiaji ${ }^{1}$, Mury Ririanty ${ }^{1}$ \\ ${ }^{1}$ Bagian Promosi Kesehatan dan Ilmu Perilaku Fakultas Kesehatan Masyarakat \\ Jl. Kalimantan I/93 Kampus Tegal Boto, Jember 68121 \\ e-mail: putrisuciwulansari@gmail.com
}

\begin{abstract}
Baby blues are often ignore so that it is undiagnose and untreate well. This situation can be a problem, because baby blues can progress to more severe emotional disorder that is postpartum depression and even postpartum psychosis. Baby blues can interfere the mother in doing her role as mother, obstruct the producing of oxytocin hormone which is causes the producing of ASI to be reduce. This research is aimed to analyze the relationship between mothers' knowledge about baby blues, birth process and parity with baby blues at RSIA Srikandi IBI in Jember District.The study was done on 4 October to 3 November 2016 with the type of analytic quantitative research bysectional approach. The total samples were 69 respondents.The analysis of data in this research used the chi square test with 95\% significant level $(\alpha=0.05)$.The analysis result showed that there was no relationship between the level of knowledge about baby and the incident of baby blues at RSIA Srikandi IBI in Jember District ( $p$ value $=0.965$ ). The analysis also showed that there was a relationship between birth process and parity with the incident of baby blues at RSIA Srikandi IBI in Jember District ( $p$ value $0.002<0.05$ ) and ( $p$ value $0.005<0.05$ ).
\end{abstract}

Keywords: Baby blues, Knowledge, Birth process, Parity

\begin{abstract}
Abstrak
Baby bluessering tidak dipedulikan sehingga tidak terdiagnosis dan tidak tertangani dengan baik. Hal ini dapat menjadi masalah, karena baby blues dapat berlanjut menjadi gangguan emosional yang lebih parah yaitu postpartum depression bahkan postpartum psikosis. Baby blues juga dapat mengganggu ibu dalam menjalankan peran sebagai ibu, menghambat pengeluaran hormon oksitoksin yang akhirnya pengeluaran ASI menjadi berkurang Penelitian ini bertujuan menganalisis hubungan antara pengetahuan ibu tentang baby blues, proses persalinan dan paritas dengan kejadian baby blues di RSIA Srikandi IBI Kabupaten Jember. Penelitian dilakukan pada 4 Oktober hingga 3 November 2016 dengan jenis penelitian analitik kuantitatif dengan pendekatan cross sectional, jumlah sampel sebanyak 69 responden. Analisis data menggunakanchi square dengan derajat kemaknaan 95\% $(\alpha=0,05)$.Hasil analisis menunjukkan bahwa tidak ada hubungan antara tingkat pengetahuan responden tentang baby blues dengan kejadian baby blues di

1 Putri Suci Wulansari, Erdi Istiaji, Mury Ririanty adalah Bagian Promosi Kesehatan dan Ilmu Perilaku Fakultas Kesehatan Masyarakat
\end{abstract}


RSIA Srikandi IBI Kabupaten Jember ( $\mathrm{p}$ value=0,965). Hasil analisis juga menunjukkan bahwa terdapat hubungan antara proses persalinan dan paritas dengan kejadian baby blues di RSIA Srikandi IBI Kabupaten Jember dengan nilai p sebesar 0,002 dan 0,005).

Kata kunci: Baby blues, Pengetahuan, Proses Persalinan, Paritas

\section{PENDAHULUAN}

Seorang wanita mempunyai reaksi emosi yang berbeda dalam menghadapi masa hamil, persalinan, dan nifas [1]. Gangguan emosional pasca persalinan dibagi menjadi tiga, yaitu postpartum blues (maternity blues atau baby blues), postpartum depression, dan postpartum psikosis[2].Baby blues dimengerti sebagai suatu sindrom gangguan efek ringan yang tampak dalam minggu pertama persalinan. Baby blues dapat terjadi sejak hari pertama pasca persalinan atau fase taking in, cenderung akan memburuk pada hari ketiga sampai kelima dan berlangsung dalam rentang waktu 14 hari atau dua minggu pasca persalinan [3]. Gejala baby blues yang paling wajar adalah perasaan sedih, mudah lelah dan amat peka secara emosional. Baby blues merupakan perasaan hipersensitif yang wajar terjadi pada ibu setelah melahirkan, tetapi yang perlu diwaspadai, hal ini dapat bertambah serius dan bertahan lama yang biasanya disebut dengan postpartum depression [4]. Postpartum depression adalah gangguan emosional pada wanita setelah persalinan dan terjadi selama beberapa bulan bahkan tahun. Gejala yang dialami wanita dengan postpartum depression lebih lama dibanding dengan baby blues. Postpartum psikosis adalah krisis psikiatri paling parah dan gejalanya dapat bermula dari baby blues atau postpartum depression[5].

Baby blues dipengaruhi oleh banyak faktor, baik faktor internal maupun faktor eksternal. Faktor internal dapat disebabkan antara lain faktor fluktuasi hormonal. Parry mengatakan bahwa: 1) hormon estrogen, meningkat selama kehamilan, dan menurun saat melahirkan, menyebabkan depresi; 2) hormon endorfrin yaitu hormon yang dapat memicu perasaan senang dan bahagia pada saat melahirkan menurun, berkontribusi terhadap kejadian depresi, 3) hormon tiroid, mengalami ketidakstabilan setelah melahirkan membuat ibu kurang bergairah [6]. Faktor internal lainnya yaitu penyakit yang menyertai ibu selama hamil dan melahirkan.Faktor eksternal yakni praktik budaya yang membatasi aktivitas ibu serta kurangnya dukungan yang diperoleh ibu selama hamil, melahirkan dan postpartum. Ketidaknyamanan fisik yang dialami wanita seperti payudara bengkak dan nyeri jahitan, rasa mulas, ketidakmampuan beradaptasi terhadap perubahan fisik emosional yang kompleks, faktor umum dan paritas, pengalaman dalam proses persalinan dan kehamilan menimbulkan gangguan pada emosional [7].

Angka baby blues mencapai 50\%80\% pada ibu baru melahirkan [8].Angka kejadian baby blues di Asia cukup tinggi dan bervariasi antara 26-85\%. Di Indonesia menurut Hidayat angka baby blues yaitu 50-70\% [5].Baby blues dapat berlanjut menjadi depresi postpartum dengan jumlah bervariasi dari 5\% hingga lebih dari $25 \%$ setelah ibu melahirkan [9] dan 1\% mengalami postpartum psikosis [5].

Penelitian terkait baby 
bluespenting dilakukan karena gangguan baby blues masih dianggap wajar sehingga seringkali terabaikan dan tidak tertangani dengan baik [5].Pengetahuan merupakan domain yang sangat penting dalam membentuk tindakan seseorang [10]. Yuliati dalam penelitiannya menyatakan bahwa terdapat hubungan antara pengetahuan dengan baby blues [11].Mansur menyatakan bahwa salah satu faktor yang mempengaruhi baby blues adalah pengalaman dan proses persalinan. Penelitian Heryanti didapatkan hasil bahwa terdapat perbedaan tingkat kecemasan antara ibu bersalin normal dan sectio caesarea. Ibu bersalin sectio caesaria memiliki tingkat kecemasan dengan kategori sangat cemas sedangkan ibu bersalin normal memiliki tingkat kecemasan dengan kategori cemas [5]. Peristiwa melahirkan dengan berbagai tindakan medis (misalnya persalinan dengan sectio caesaria) akan menghantui psikologis ibu sebagai stressor yang bermakna sehingga bisa menjadi dorongan munculnya baby blues pada saat ibu memasuki masa nifas [12]. Baby blues dapat terjadi pada semua ibu postpartum dari etnik dan ras manapun serta pada ibu primipara maupun multipara. Machmudah dalam penelitiannya menyebutkan bahwa terdapat hubungan antara paritas dengan baby blues. Ibu primipara merupakan kelompok yang paling rentan mengalami baby blues.Baby blues dapat dipicu oleh perasaan belum siap menghadapi lahirnya bayi dan tanggung jawab atas peran baru sebagai ibu[13].

Smith et al dampakbaby blues pada ibu adalah dapat mengganggu kemampuan ibu dalam menjalankan peran, salah satunya merawat bayi sehingga mempengaruhi kualitas hubungan antara ibu dan bayi [14]. Baby blues pada ibu menyusui akan menghambat pengeluaran oksitoksinyang akhirnya mengurangi ASI [7].Akibatnya, dalam jangka waktu pendek bayi akan mengalami kekurangan nutrisi karena tidak mendapatkan asupan ASI dan hubungan emosional kurang terjalin serta dalamjangka waktu panjang akan menyebabkan keterlambatan perkembangan, mengalami gangguan emosional dan masalah sosial [14]. Tiga ciri khas anak yang mengalami keterlantaran dari ibu, yaitu: inteligensi terlambat, sangat emosional dan maturasi kejiwaan terganggu [15].Mengacu konsep sehat dari WHO (World Health Organization) yakni suatu keadaan sempurna baik fisik, mental maupun sosial, tidak hanya terbebas dari penyakit atau kelemahan/cacat [16] sehingga sangat diharapkan ibu-ibu dapat menjalani masa hamil, bersalin, dan nifas dalam keadaan sehat dan bahagia [1].

RSIA (Rumah Sakit Ibu dan Anak)

Srikandi IBI Kabupaten Jember merupakan Rumah Sakit Ibu dan Anak di Kabupaten Jember.Berdasarkan studi pendahuluan yang dilakukan oleh peneliti, didapatkan data persalinan selama tiga tahun terakhir yakni tahun 2013 hingga 2015. Selama tiga tahun terakhir, terdapat angka persalinan sebanyak 4221 pasien, dari jumlah tersebut terdapat 1406 pasien yang melahirkan secara normal, dan secara sectio caesaria sebanyak 2815 pasien.Wawancara dilakukan kepada 15 responden di ruang Gatotkaca dan Damayanti pada tanggal 15-24 Februari 2016 dengan metode persalinan normal dan sectio caesaria. Hasil pengisian kuesioner menunjukkan dari total 15 responden, sebagian besar responden yakni sebanyak 12 responden (80\%)menyatakan belum pernah mengetahui tentang istilah baby blues, dan hanya 3 responden (20\%) menyatakan pernah mengetahui istilah 
baby blues.Responden mengetahui informasi baby blues dari membaca maupun melihat televisi.

Pengisian kuesioner Edinburgh

Postnatal Depression Scale (EPDS) didapatkan hasil bahwa terdapat 5 responden $\quad(33,33 \%)$ kemungkinan mengalami baby blues, 8 responden (53,33\%) mengalami baby blues, 1 responden $\quad(6,67 \%)$ kemungkinan mengalami postpartum depression, dan 1 responden $\quad(6,67 \%) \quad$ mengalami postpartum depression. Data tersebut menggambarkan bahwa ibu pasca melahirkan di RSIA Srikandi IBI Jember sebagian besar mengalami baby blues. Hingga saat ini di RSIA Srikandi IBI Jember belum dilakukan skrining untuk mengetahui gambaran baby blues ibu pasca melahirkan. Berdasarkan hal tersebut, peneliti ingin meneliti hubungan antara pengetahuan ibu tentang baby blues, prosespersalinan dan paritas dengan baby blues di RSIA Srikandi IBI Kabupaten Jember.

\section{METODE PENELITIAN}

Jenis penelitian dalam penelitian ini adalah analitik kuantitatif dengan desain cross sectional. Penelitian dilakukan di RSIA Srikandi IBI Kabupaten Jember pada 4 Oktober hingga 3 November 2016. Populasi penelitian yakni ibu pasca melahirkan di RSIA Srikandi IBI Kabupaten Jember dengan sampel penelitian berjumlah 69 responden. Teknik pengambilan sampel menggunakan systematic random sampling, yakni pengambilan sampel secara random hanya dilakukan pada unsur pertama dalam populasi, sedangkan unsur selanjutnya mengikuti interval tertentu. Teknik pengumpulan data melalui data primer maupun data sekunder. Data primer dalam penelitian yakni data pengetahuan ibu tentang baby blues dan paritas responden. Data primer diperoleh melalui wawancara dengan kuesioner. Kuesioner pengetahuan tentang baby blues terdiri dari 18 pertanyaan yang telah dilakukan uji validitas dan reliabilitas oleh peneliti, dan didapatkan hasil valid dan reliabel. Data sekunder yakni data pasien bersalin dan proses persalinan responden. Pengukuran baby blues menggunakan kuesioner EPDS dari Cox, Holden dan Sagovsky, yakni kuesioner untuk skrining gangguan mental ringan seperti baby blues yangtelah terbukti valid dan reliabel digunakan pada wanita Indonesia. Teknik analisis data bivariat menggunakan uji Chi-Square dengan tingkat kemaknaan 95\%.

\section{HASIL PENELITIAN}

\section{Karakteristik Responden Penelitian}

Karakteristik responden dalam penelitian ini adalah umur, tingkat pendidikan, status pekerjaan, pengetahuan tentang baby blues, proses persalinan, dan paritas responden. Distribusi karakteristik responden penelitian dapat dilihat pada tabel berikut: 
Tabel 1. Distribusi frekuensi berdasarkan umur, tingkat pendidikan status pekerjaan, pengetahuan tentang baby blues, proses persalinan, dan paritas responden

\begin{tabular}{lcc}
\hline \multicolumn{1}{c}{ Karakteristik Responden } & n & Persen (\%) \\
\hline Umur & 10 & 14,5 \\
$15-20$ & 22 & 31,9 \\
$21-25$ & 13 & 18,8 \\
$26-30$ & 17 & 24,6 \\
$31-35$ & 7 & 10,1 \\
$>35$ & & \\
\hline Tingkat Pendidikan & 1 & 1,4 \\
Tidak tamat SD & 7 & 10,1 \\
SD/sederajat & 18 & 26,1 \\
SMP/sederajat & 36 & 52,2 \\
SMA/sederajat & 7 & 10,1 \\
Perguruan tinggi & & \\
\hline Status Pekerjaan & 15 & 21,7 \\
Bekerja & 54 & 78,3 \\
Tidak Bekerja & & \\
\hline Pengetahuan Tentang Baby & & 44,9 \\
Blues & 31 & 40,6 \\
Kurang & 28 & 14,5 \\
Sedang & 10 & 20,3 \\
Baik & & 79,7 \\
\hline Proses Persalinan & 14 & 42,0 \\
Normal & 55 & 58,0 \\
Sectio Caesarea & & \\
\hline Paritas & 29 & \\
Primipara & 40 & \\
Multipara & & \\
\hline
\end{tabular}

Tabel 1 menunjukkan bahwa mayoritas responden pada penelitian ini berumur 21-25 tahun (31,9\%), berpendidikan terakhir SMA/sederajat (52,2\%), tidak bekerja $\quad(78,3 \%)$, pengetahuan responden tentang baby blues kurang $(44,9 \%)$ proses persalinan dengan sectio caesarea $(79,7 \%)$, dan status paritas multipara (58\%).

\section{Kejadian Baby Blues}

Baby blues merupakan gangguan emosional pasca melahirkan, paling lama berlangsung hingga dua minggu setelah kelahiran dan biasanya memburuk pada hari ketiga hingga kelima. Berikut ini distribusi frekuensi kejadian baby blues responden yaitu:

Tabel 2. Distribusi frekuensi kejadian baby blues responden

\begin{tabular}{lcc}
\hline \multicolumn{1}{c}{ Kejadian Baby Blues } & n & Persen (\%) \\
\hline Tidak baby blues & 25 & 36,2 \\
Baby blues & 44 & 63,8 \\
\hline Jumlah & 69 & 100 \\
\hline
\end{tabular}


Tabel 2 menunjukkan bahwa mayoritas responden pada penelitian ini mengalami baby blues (63,8\%). (58\%).

\section{Hubungan Antara Pengetahuan Ibu tentang Baby Blues dengan Kejadian Baby Blues}

Analisis hubungan antara pengetahuan ibu tentang baby blues dengan kejadian baby blues responden dalam penelitian ini menggunakan uji chi square. Hasil yang diperoleh dari analisis tersebut yakni:

Tabel 3. Analisis hubungan pengetahuan ibu tentang baby blues dengan kejadian baby blues responden.

\begin{tabular}{|c|c|c|c|c|c|c|}
\hline \multirow{3}{*}{ Pengetahuan } & \multicolumn{4}{|c|}{ Status } & \multirow{3}{*}{ p-value } & \multirow{3}{*}{ OR (95\%CI) } \\
\hline & \multicolumn{2}{|c|}{ Tidak BB } & \multicolumn{2}{|r|}{ BB } & & \\
\hline & n & $\%$ & $\mathbf{N}$ & $\%$ & & \\
\hline Kurang & 11 & 15,9 & 20 & 29,0 & & 1 \\
\hline Sedang & 10 & 14,5 & 18 & 26,1 & & $1,010(0,347$ \\
\hline & & & & & 0,965 & $2,937)$ \\
\hline Baik & 4 & 5,8 & 6 & 8,7 & & $\begin{array}{c}1,212(0,281 \\
5,238)\end{array}$ \\
\hline Jumlah & 25 & 36,2 & 44 & 63,8 & & \\
\hline
\end{tabular}

Tabel 3 menjelaskan mengenai hubungan pengetahuan dengan kejadian baby blues. Sebagian besar responden yang mengalami baby bluesberada pada tingkat pengetahuan kurang $(29,0 \%)$ dan tidak ada hubungan antara pengetahuan tentang baby blues dengan kejadian baby blues.

$\begin{array}{llr}\text { Hubungan Antara } & \text { Proses } \\ \text { Persalinandengan } & \text { Kejadian } & \text { Baby } \\ \text { Blues } & & \end{array}$

Analisis hubungan antara proses persalinandengan kejadian baby blues menggunakan uji chi square. Hasil dari analisis tersebut yakni

Tabel 4. Analisis hubungan antara proses persalinandengan kejadian baby blues responden

\begin{tabular}{lcccccccc}
\hline \multicolumn{1}{c}{ Proses } & \multicolumn{4}{c}{ Status } & & & \multicolumn{2}{c}{ OR (95\%CI) } \\
\multicolumn{1}{c}{ Persalinan } & Tidak BB & & BB & & $\boldsymbol{p}$-value & & \\
& n & \% & n & \% & & & \\
\hline Normal & 10 & 14.5 & 4 & 5,8 & & 1 \\
Sectio caesarea & 15 & 21,7 & 40 & 58,0 & 0,002 & 6,667 & $(1,812-$ \\
& & & & & & 24,525 & \\
\hline Jumlah & 25 & 36,2 & 44 & 63,8 & & & \\
\hline
\end{tabular}

Tabel 4 menjelaskan hubungan antara proses persalinan dengan kejadian baby blues. Mayoritas responden yang mengalami baby bluesm Putrisuci responden dengan persalina Putri Suci caesarea (58,0\%), terdapat hubungan Hubungan Antara Paritasdengan antara proses persalinandengan kejadian baby blues, dan ibu yang melahirkan secara sectio caesarea memiliki risiko 6,7 ,. , .. ., . , ,

ari :Hubungan Antara Pengetahuan..... 46 melahirkan secara normal. 
Tabel 5. Analisis hubungan antara paritasdengan kejadian baby blues responden.

\begin{tabular}{|c|c|c|c|c|c|c|}
\hline \multirow{3}{*}{ Paritas } & \multicolumn{4}{|c|}{ Status } & \multirow{3}{*}{ p-value } & \multirow{3}{*}{ OR $(95 \% \mathrm{CI})$} \\
\hline & \multicolumn{2}{|c|}{ Tidak BB } & \multicolumn{2}{|r|}{ BB } & & \\
\hline & n & $\%$ & $\mathbf{n}$ & $\%$ & & \\
\hline Primipara & 5 & 7,2 & 24 & 5,8 & 0,005 & $\begin{array}{c}4,8(1,526- \\
15,093)\end{array}$ \\
\hline Multipara & 20 & 29 & 20 & 58,0 & & 1 \\
\hline Jumlah & 25 & 36,2 & 44 & 63,8 & & \\
\hline
\end{tabular}

Tabel 5 menjelaskan hubungan antara paritasdengan kejadian baby blues. Mayoritas responden yang mengalami baby bluesmerupakan responden dengan status paritas primipara(34,8\%), terdapat hubungan antara proses persalinandengan kejadian baby blues, ibu dengan status paritas primiparamemiliki risiko 4,8 kali lebih besar mengalami baby blues dibandingkan dengan ibu dengan status paritas multipara.

\section{HASIL DAN PEMBAHASAN}

Hasil penelitian menunjukkan bahwamayoritas responden berumur 2125 tahun. Usia aman untuk kehamilan dan persalinan dalam kurun reproduksi sehat adalah rentang 20 hingga 35 tahun, sehingga dapat disimpulkan mayoritas responden berdasarkan umur berada pada kategori aman untuk hamil dan persalinan. Hal ini sesuai dengan pernyataan Ekasari bahwa umur ketika hamil sangat berpengaruh pada kesiapan ibu untuk menerima tanggung jawab sebagai seorang ibu sehingga kualitas sumber daya manusia makin meningkat dan kesiapan untuk menyehatkan generasi penerus dapat terjamin [17].

Tingkat pendidikan terakhir responden mayoritas adalah SMA sederajat. Marmi menyatakan bahwa tingkat pendidikan berkaitan dengan pengetahuan tentang masalah kesehatan dan kehamilan yang berpengaruh pada perilaku ibu, baik pada diri maupun terhadap perawatan kehamilannya serta pemenuhan gizi saat hamil [17]. Pendidikan rendah dapat mengakibatkan keterbatasan pengetahuan sehingga menyebabkan ibu postpartum mempunyai persepsi dan sikap negatif terhadap penerimaan keadaan yang tidak menguntungkan. Wanita yang berpendidikan tinggi menghadapi tekanan sosial dan konflik peran antara tuntutansebagai wanita berpendidikan tinggi yang memiliki dorongan untuk bekerja dan melakukan aktivitas di luar rumah dan peran sebagai ibu rumah tangga atau sebagai orang tua ketika ia memiliki anak [18].

Mayoritas responden penelitian berstatus tidak bekerja atau ibu rumah tangga. Ibu rumah tangga yang mengurus anak dapat mengalami baby blues karena lelah dan letih yang dirasakan. Sejalan dengan pernyataan Fatmawatidalam penelitiannya menyebutkan bahwa baby blues terjadi pada sebagian besar ibu postpartum yang tidak bekerja atau ibu rumah tangga sebesar 51\%, namun hasil

47 Jurnal IKESMA Volume 13 Nomor 1 Maret 2017

faktor risiko stäus p̌ pekerjaan ibu terhadap baby blues[18].

Pengetahuan responden tentang baby blues mayoritas berada pada kategori kurang. Pengetahuan 
merupakan domain yang sangat penting dalam membentuk tindakan seseorang [10].Pengetahuan sangat erat hubungannya dengan pendidikan, dimana diharapkan bahwa dengan pendidikan yang tinggi maka orang tersebut akan semakin luas pengetahuannya. Akan tetapi perlu ditekankan, bukan berarti seseorang yang berpendidikan rendah mutlak berpengetahuan rendah pula [19].Hasil penelitian ini juga menunjukkan bahwa mayoritas tingkat pengetahuan responden tentang baby blues dengan pendidikan terakhir perguruan tinggi berada pada kategori baik, SMA sederajat berada pada kategori sedang, sedangkan untuk SMP, SD dan tidak tamat SD berada pada kategori kurang. Hal ini menunjukkan bahwa pendidikan mempengaruhi proses belajar, semakin tinggi pendidikan seseorang, maka semakin mudah pula orang tersebut untuk menerima informasi baik dari orang lain maupun dari media massa.

Proses persalinan responden sebagian besar sectio caesarea. Peristiwa melahirkan dengan tindakan medis akan menghantui psikologis ibu sebagai stressor yang bermakna sehingga terbawa terus sampai masa nifas, (misalnya persalinan dengan tindakan sectio caesaria). Peristiwa persalinan seperti ini bisa menjadi dorongan munculnya depresi postpartum saat ibu memasuki masa nifas [19].

Paritas responden mayoritas adalah multipara. Sebagian ibu menyambut kehamilan dengan gembira namun tidak jarang stres dan cemas muncul.Stres pada ibu multipara dapat disebabkan karena pengalaman melahirkan sebelumnya yang tidak menyenangkan, memikirkan harus mengurus bayi, anak, suami dan pekerjaan rumah, serta kelelahan [5].

Hasil penelitian menggunakan
EPDS menunjukkansebagian besar responden mengalami baby blues. Gejala baby blues yang dirasakan responden antara lain: cemas, panik, sulit tidur, perasaan sedih, menangis, dan masih kesulitan untuk melakukan perannya. Beberapa responden menyatakan bahwa pernah ada pikiran untuk menyakiti atau menciderai diri sendiri.Baby blues yang dialami responden pada minggu pertama umumnya disebabkan karena rasa nyeri dan cemas yang berkepanjangan. Hal ini sesuai dengan teori Meser, yang menyatakan bahwa kecemasan dan keraguan akan kemampuan diri merupakan perasaan yang wajar.Hal ini dialami ketika seorang ibu belum bisa melepaskan diri dari kelelahan akibat persalinan. Kondisi emosional yang tidak menentu disebabkan karena adanya perubahan hormon dan pola tidur [20].

Hasil analisis bivariat dengan chi square diketahui bahwa tidak terdapat hubungan antara pengetahuan responden tentang baby blues dengan kejadian baby blues. Baby blues terjadi pada ibu postpartum dengan tingkat pengetahuan kurang, sedang, serta baik. Tetapi mayoritas terjadi pada ibu dengan tingkat pengetahuan kurang dan secara statistik tidak terdapat hubungan yang bermakna. Hal ini berbeda dengan penelitian Yuliati di wilayah kerja Puskesmas Kajhu Kecamatan Baitussalam Kabupaten Aceh. Yuliati menyatakan bahwa terdapat hubungan antara pengetahuan dengan baby blues[11]. Perbedaan hasil penelitian tersebut dapat disebabkan berbagai faktor.Faktor perbedaan metode penelitian, karakteristik ibu postpartum, lokasi penelitian yang berbeda, dukungan sosial, maupun budaya serta lingkungan sekitar ibu postpartum yang berbeda. Selain itu, adanya faktor lain yang juga dapat menjadi pemicu terjadinya baby blues, dalam penelitian 
ini yakni proses persalinan dan paritas dan faktor lain yang tidak diteliti dalam penelitian ini, misalnya dukungan sosial, budaya dalam masyarakat yang dapat berpengaruh terhadap terjadinya baby blues. Notoatmodjo mengatakan faktor penentu atau determinan perilaku yang sulit untuk dibatasi karena perilaku merupakan resultansi dari berbagai faktor, baik internal maupun eksternal (lingkungan) [21].Azwar menyebutkan faktor lingkungan memiliki kekuatan besar dalam menentukan perilaku, bahkan terkadang kekuatannya lebih besar daripada karakteristik individu itu sendiri [22].Lingkungan yang diciptakan manusia dapat memberikan penguat yang positif dan negatif. Lingkungan disekitar responden merupakan salah satu faktor yang dapat mempengaruhi perilaku ibu, dalam hal ini yaitu baby blues pada ibu postpartum.Lingkungan yang mendukung dapat mendorong ibu untuk berperilaku sehat.

Analisis hubungan antara proses persalinan dengan kejadian baby blues didapatkan hasil bahwa mayoritas responden yang mengalami baby blues adalah responden dengan proses persalinan secara sectio caesarea.Uji chi square didapatkan hasil bahwa terdapat hubungan yang bermakna antara proses persalinandengan kejadian baby blues, danibu yang melahirkan secara sectio caesarea memiliki risiko 6,7 kali lebih besar mengalami baby blues dibandingkan dengan ibu yang melahirkan secara normal.Penelitian ini sejalan dengan penelitian yang dilakukan oleh Gonidakis.Penelitian dilakukan pada ibu postpartum selama tiga hari pertama persalinan. Gonadakis menyatakan bahwa persalinan dengan sectio caesarea berhubungan dengan baby blues[23]. Mansur menyatakan bahwa salah satu faktor yang mempengaruhi baby blues adalah pengalaman dan proses kehamilan dan persalinan. Pengalaman traumatik, misalnya ibu yang melahirkan dengan sectio caesareadapat memunculkan trauma psikis pada ibu yang mengalaminya. Peristiwa melahirkan dengan berbagai tindakan medis akan menghantui psikologis ibu sebagai stressor yang bermakna sehingga terbawa terus sampai masa nifas, (misalnya persalinan dengan tindakan sectio caesaria).Peristiwa persalinan seperti ini bisa menjadi dorongan munculnya depresi postpartum saat ibu memasuki masa nifas [19].Penelitian ini juga menunjukkan bahwa mayoritas ibu melahirkan dengan sectio caesarea kadang-kadang merasa kesulitan dalam melakukan segala sesuatu sebanyak 35 $(50,7 \%)$ responden, sedangkan pada ibu bersalin normal mayoritas menjawab tidak kesulitan dan mampu mengatasi segala hal yakni sebanyak 7 (10,1\%) responden. Rasa nyeri yang timbul akibat sectio caesarea dapat mengganggu aktivitas ibu pasca melahirkan dalam menjalankan peran, misalnya kesulitan untuk mengatur posisi yang nyaman saat menyusui dan kesulitan dalam merawat 49 Jurnal IKESMA Volume 13 Nomor 1 Maret 2017

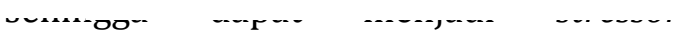
terjadinya baby blues.

Analisis hubungan antara paritas dengan kejadian baby blues didapatkan hasil bahwa sebagian besar responden yang mengalami baby blues adalah responden dengan paritas primipara atau responden yang baru pertama kali melahirkan. Hasil penelitian menunjukkan adanya hubungan yang bermakna antara paritas dengan kejadian baby blues, danibu dengan status paritas primiparamemiliki risiko 4,8 kali lebih besar mengalami baby blues dibandingkan dengan ibu dengan status paritas multipara. Penelitian ini didukung denganpenelitian Machmudah bahwa terdapat hubungan antara paritas 
dengan kejadian baby blues[13]. Ibu primipara lebih berisiko mengalami baby blues, karena pada ibu primipara merupakan persalinan dan pengalaman pertama sehingga ibu kurang siap untuk menghadapi persalinan. Wanita primipara berada dalam proses adaptasi, jika sebelum memiliki anak hanya memikirkan diri sendiri begitu bayi lahir apabila ibu tidak paham dengan perannya ia akan kebingungan sementara bayinya harus tetap dirawat [25]. Bobak et al menyatakan bahwa ibu primipara yang belum berpengalaman dalam pengasuhan anak termasuk salah satu kriteria ibu yang rentan mengalami gangguan emosional dan membutuhkan dukungan tambahan [9].Kondisi emosional salah satunya ditandai dengan menangis.Penelitian ini menunjukkan bahwa mayoritas ibu primipara menjawab mereka menangis karena merasa tidak bahagia pada saat tertentu saja yakni sebanyak $13 \quad(18,8 \%)$ responden, sedangkan ibu multipara mayoritas menjawab tidak pernah menangis karena tidak merasa bahagia yakni sebanyak $26 \quad(37,7 \%)$ responden.Ibu primipara dapat merasakan takut dan khawatir melakukan kesalahan dalam merawat bayi. Ibu primipara juga merasakan kebingungan dalam melakukan tugasnya, lebih terbebani dan merasa kebebasannya berkurang dengan hadirnya seorang anak [17].Penelitian ini juga menunjukkan bahwa ibu primipara mayoritas hampir setiap saat merasa kesulitan dalam mengerjakan segala sesuatu, sebanyak $14(20,3 \%)$ responden sedangkan ibu multipara mayoritas menjawab kadang-kadang tidak mampu mengatasi segala hal sebaik biasanya, yakni sebanyak $28(40,6 \%)$ responden.

\section{SIMPULAN DAN SARAN}

Berdasarkan hasil analisis dan pembahasan yang telah dilakukan, dapat disimpulkan bahwaresponden penelitian mayoritas berumur 21-25 tahun, tingkat pendidikan terakhir SMA sederajat, tidak bekerja, pengetahuan tentang baby blues berada dalam ketegori kurang, proses persalinan secara sectio caesarea dan status paritas multipara, responden mayoritas mengalami baby blues. Tidak terdapat hubungan antara pengetahuan ibu tentang baby blues dengan kejadian baby blues, hal ini karena adanya faktor lain yang juga dapat menjadi pemicu terjadinya baby blues dalam penelitian ini yakni proses persalinan dan paritas. Selain itu adanya faktor lain yang tidak diteliti dalam penelitian ini, misalnya dukungan sosial, budaya dalam masyarakat yang dapat berpengaruh terhadap terjadinya baby blues.Hasil analisis menunjukkan bahwa terdapat hubungan antara proses persalinan dengan kejadian baby blues pada ibu pasca melahirkan di RSIA Srikandi IBI Kabupaten Jember, dan ibu bersalin dengan sectio caesarea berisiko 6,7 kali lebih besar untuk mengalami baby blues daripada ibu bersalin normal. Rasa nyeri akibat persalinan secara sectio caesareadapat memicu terjadinya baby blues karena nyeri akibat operasi mengganggu aktivitas ibu dalam menjalankan perannya sehari-hari.Hasil analisis menunjukkan bahwa terdapat hubungan antara paritas dengan kejadian baby blues pada ibu pasca melahirkan di RSIA Srikandi IBIKabupaten Jember, dan ibu primipara berisiko 4,8 k ${ }^{\prime} \cdot \cdots$ besar untuk mengalami bai Putri Suci Wulansari:Hubun daripada ibu multipara. Ibu primipara lebih rentan mengalami baby blues berkaitan dengan kurangnya pengalaman dalam menjalankan peran barunya sebagai ibu.

$$
\text { Saran yang diberikan oleh }
$$


peneliti adalah perlunya dilakukan penyuluhan dan pelatihan terkait perawatan bayi dan perawatan diri ibu setelah persalinan terutama bagi ibu primipara dan ibu bersalin dengan sectio caesaria. Materi penyuluhan dan pelatihan misalnya: breast feeding, perawatan tali pusat, perawatan diri pasca operasi, serta terkait dengan perubahan peran sebagai ibu. Screening baby blues juga dapat dilakukan menggunakan EPDS. Perlu dilakukan penanganan terhadap pasien yang mengalami baby blues. Pihak rumah sakit dapat bekerjasama atau menambahkan tenaga profesional yang dapat membantu menangani permasalahan baby blues. Selain itu, perlunya kesadaran dari suami dan keluarga untuk memberikan dukungan pada ibu pasca melahirkan. Peneliti selanjutnya, diharapkan dapat melakukan penelitian lebih mendalam tentang baby blues dengan faktor penyebab yang berbeda. Misalnya proses persalinan (melalui ekstraksi forcep, ektraksi vakum), faktor ekonomi keluarga, budaya di masyarakat. Penelitian dapat dilakukan secara kualitatif.

\section{DAFTAR RUJUKAN}

[1] Suryati. The Baby Blues and Postnatal Depression. Jurnal Kesehatan Masyarakat. 2008. 2(2) 191-193. Available from http://jurnal.fkm.unand.ac.id/inde x.php/jkma/article/view/32

[2] Marshall F. Mengatasi Depresi Pasca Melahirkan. Jakarta: Arcan; 2006

[3] Meilina AR, MappawareNA, Budu. Hubungan Lama Persalinan dengan Kejadian Postpartum Blues. [internet]. 2014. [diakses tanggal 23 November 2015] Available from: http://pasca.unhas.ac.id

[4] Feinmann. Ensiklopedi Kesehatan Wanita. Surabaya: Penerbit Erlangga;2011

[5] Yodatama DC. Hubungan Bonding Attachment dengan Resiko Terjadinya Postpartum Blues pada Ibu Postpartum dengan Sectio Caesaria di Rumah Sakit Ibu dan Anak (RSIA) Srikandi IBI Kabupaten Jember. Universitas Jember. 2014

[6] Manurung, Lestari, Suryati, Miradwiyana, Karma, dan Paulina. Efektivitas Terapi Musik Terhadap Pencegahan Postpartum Blues pada Ibu Primipara di Ruang Kebidanan RSUP Cipto Mangunkusumo Jakarta Pusat. Buletin Penelitian Sistem Kesehatan. 2011. 14(1) 17-23

[7] Wulandari IH. Tingkat Kecemasan Ibu Postpartum yang Asinya Tidak Lancar di Ruang Bersalin RSUD Dr. Abdoer Rahem Situbondo. [internet]. 2014. [diakses tanggal 27 Desember 2015] Available from:http://repository.poltekesma japahit.ac.id

[8] Thurgood S, Avery DM,Williamson L. Postpartum Depression (PDD).American Journal of Clinical Medicine. 2009. 6(2) 17-22

[9] RahmandaniA. Strategi Penanggulangan (Coping) pada Ibu yang Mengalami Postpartum Blues di Rumah Sakit Umum Daerah Kota Semarang. Skripsi. Fakultas

51 Jurnal IKESMA Volume 13 Nomor 1 Maret 2017

[10] NotoatmodjoS. Promosi Kesehatan danPerilaku Kesehatan. Jakarta: Rineka Cipta; 2012

[11] Yuliati. Faktor-faktor yang Berhubungan dengan Postpartum Blues pada Ibu Pasca Persalinan di Wilayah Kerja Puskesmas Kajhu 
Kecamatan Baitussalam Kabupaten Aceh Besar Tahun 2013. [internet]. 2014. [diakses 21 November 2016] Available

from:http://simtakp.uui.ac.id/dock ti/YULIANTI-

skrisi_bab_i,ii,iii,iv,v.pdf

[12] Indriyani. Aplikasi Konsep \& Teori Keperawatan Maternitas Postpartum dengan Kematian Janin. Jogjakarta: Ar-Ruzz Media; 2013

[13] Machmudah. Pengaruh Persalinan dengan Komplikasi terhadap Kemungkinan Terjadinya Postpartum Blues di Kota Semarang.[internet] 2010. [diakses 23 Desember 2015] Available from:

http://lontar.ui.ac.id/file?file=digit al/20284389-

T\%20Machmudah.pdf.

[14] Smith, Segal. Postpartum Depression and Postpartum Blues. [internet]. 2012. [diakses 30 Desember 2015] Available from:http://www.helpguide.org/m ental/postpartum_depression/

[15] Latipun, NotosoedirdjoM. Kesehatan Mental Konsep dan Penerapan.Malang: UPT Penerbitan Universitas Muhammadiyah Malang; 2014

[16] Latipun. Kesehatan Mental Konsep dan Penerapan.Malang: UPT Penerbitan Universitas Muhammadiyah Malang; 2011

[17] EkasariW. Pengaruh Umur Ibu,
Paritas, Usia Kehamilan, dan Berat Lahir Bayi terhadap Asfiksia Bayi pada Ibu Pre-Eklamsia Berat. Tesis. Program Studi Ilmu Kesehatan Masyarakat Program Pasca Sarjana Universitas Sebelas Maret. Jakarta; 2015

[18] FatmawatiD. Faktor Risiko yang Berpengaruh terhadap Kejadian Postpartum Blues.. Jurnal Edu Healt. 2015. 5(2) 82-93

[19] Wawan A, Dewi M. Teori dan Pengukuran Pengetahuan, Sikap, dan Perilaku Manusia. Yogyakarta: Nuha Medika; 2010

[20] Meser A. 9 Bulan yang Mendebarkan. Yogyakata: Elmatera; 2009

[21] Notoatmodjo. Promosi Kesehatan dan Ilmu Perilaku.Jakarta: Rineka Cipta; 2007

[22] Azwar S. Sikap Manusia Teori dan Pengukurannya. Yogyakarta: Pustaka Pelajar Offset; 2009

[23] Gonidakis F, Rabavilas A. Maternity Blues in Athens, Greece: A Study During The First 3 Days After Delivery. Journal Affect Disorder. 2007. 9(9) 193-194

[25] Masruroh. Hubungan Antara Paritas Ibu dengan Kejadian Postpartum Blues. [internet] 2013. [diakses 17 November 2016] Available from: http://www.journal.unipdu.ac.id/i ndex.php/eduhealth/article/view/ 333 